\title{
Regulation of Directors Non-Competition Obligation under Ethiopia Commercial Code: A Lesson from Turkish Legal Experiences
}

\author{
Yusuf Ibrahim SAED \\ Faculty of Law, Dokuz Eylül University, 35678, Izmir, Turkey
}

\begin{abstract}
Ethiopia Commercial Code (ECC) obligated the directors to do activities that bolstered corporate economic activities. It also prohibited corporate directors not to do activities that infringe the interest of companies such as not to compete against their companies while also retaining the directorships chair. Unlike the Turkish legal framework that tried to include important insiders under the scope of non-competition obligation, ECC only prohibited corporate directors not to compete against the company's business transaction without general assembly approval. Except Corporate directors and general partner, managers of private limited companies, and other remaining partners of business organization are not also under obligation of non-competition. The scope of the business activities prohibited by the Turkish Commercial code is also clearly comprehensible and clear enough to delineate the boundaries of transactions far more than ECC. Additionally, the given legal remedies for breach of the non-competition obligation under ECC and Turkish Commercial Code are different in terms of the option, procedural easiness to execute, offered legal countermeasures, and building investor trust on corporate governance system. This work is intended to grasp helpful experiences of the Turkish legal system regulation of the noncompetition obligation of corporate management for Ethiopia legislative further consideration.
\end{abstract}

Keywords: Director, Non-competition Obligation, Corporate Activities, Scope, Remedies.

DOI: $10.7176 / \mathrm{JLPG} / 101-04$

Publication date:September $30^{\text {th }} 2020$

\section{Introduction}

We are in a situation of competitive positioning world order that everybody wants to win the case but in reality, a few numbers win the race. This can be observed from a business of corporate activities that endeavor locally but striving to be a global giant in a collective manner through amassing capital and skill together. As far as the competition took place within regulated hippodrome, the altogether will be benefited from the competition. In this case, the steering wheel and whistle of the company are mainly at the hands of directors who piloted the limited liability companies for the wellbeing of companies, shareholders, and the societies. While steering the wheel of the corporate, the management should concern for the corporate reputation that could be earned hardly through number of advert and positive image building in front of the community at large but can mislay such reputation during its endeavor due to internal imperfection and blemish activities ${ }^{1}$.

Notwithstanding contract terms of employment, every director of Limited Liability Companies owes fiduciary duties to the company. But they also beholden this fiduciary obligation to shareholders and creditors of the company in case liability issues began to set in motion ${ }^{2}$. During their directorship tenure, corporate directors can act against their fiduciary duty in abounding ways if they have awful intentions through abusive insider behavior of corporate tunneling that includes self-dealing and non-controlled insider trading ${ }^{3}$. It is not only the director but any corporate insider who has an informational advantage of the corporation's strategic and functional activities can abuse corporations from inside via competing against the corporation. This could take place before resignation from the board members of the company. Hence it is possible to classify the director's non-competition obligation into pre-termination (resignation) and post-termination (post-contractual) non-competing obligation. The former is a fiduciary duty of directors not to compete against the competition while they are inside the corporation as a member of the board of directors ${ }^{4}$. Whereas the latter is a directors responsibility (including agreement) that restrict them from competing against their former corporation after leaving the company using

\footnotetext{
${ }^{1}$ To know more about corporate reputation read, IDOWU, Samuel (ed)/ Caliyurt, Kiymet(ed): Corporate Governance, an International Perspective, book Series no.3, Springer Science \& Business Media, 2014, p. 229.

${ }^{2}$ Keay, Andrew: Company Directors' Responsibilities To Creditors, Taylor \& Francis, 2007. P. 32. See Also, Martin, David: The Company Director's Desktop Guide 6th Edition, 2007, P. 223. See Also, Bourne, Nicholas: Essential Company, 2000, P. 59. See Also, Commercial Code of the Empire Of Ethiopia (Hereinafter Ecc), Proclamation No. 166, 1960, Article 364,365,366 And 367.

${ }^{3}$ See, Pacces, Alessio: Rethinking Corporate Governance The Law and Economics of Control Powers, Routledge, London, 2012, P. 233 And The Ff.; See Also, Idowu/ Caliyurt, 2014, P. 303.

${ }^{4}$ Read To Extract, Christie, Michael: The Director's Fiduciary Duty Not To Compete, The Modern Law Review, Vol. 55, 4, 1992, P. 507, 508. Read Also, Editors, Law Review (1935) "Duty Of A Director Not To Compete With His Corporation," University Of Chicago Law Review: Vol. 2: Issue. 2, Article 36. P. 324

Available At: Https://Chicagounbound.Uchicago.Edu/Uclrev/Vol2/Iss2/36,
} 
inside information they obtained during their reign of directorships such as company pricing information, established customer relationship, market assessment, situational studies and other strategic advantages of companies $^{1}$. To impede such malpractice of irresponsible directors, company laws of every country entrusted them with different obligations while overseeing Limited Liability Corporation. The non-competing obligation is one of these duties enshrined in each countries legal framework ${ }^{2}$.

\section{Directors Competition with Company}

Director non-competition obligation is the duty of directors that emanate from fiduciary not to compete in person directly or indirectly through invisible hands with their company by infringing his/her loyalty entrusted to them ${ }^{3}$. Now a day this obligation includes the restriction of being a director in any similar companies performing the same business transaction within the same areas of activities. The non-Competition obligation of directors or other senior management of companies is an exception to the principle of free competition. This prohibition restricts individual person freedom to trade in some field of undertaking. The right of a director to compete with his corporation involves the nature and extent of the director's fiduciary obligation to the corporation and its shareholders ${ }^{4}$. But to what extent is a director of the company able to compete with the company of which he is a director, either through another company as a director or possibly through a partnership, or, indeed, trading as a sole trader without breaching fiduciary duty was a point of contention among scholars since the beginning of the $20^{\text {th }}$ century ${ }^{5}$. This was triggered by 1890 judgments of Chitty $\mathrm{J}$ and Lord Blanesburgh that was widely regarded as constituting authority for the proposition that a director can compete with his or her company or can act as a director of a rival company $^{6}$. It was this New Mashonaland case that sparks the possibility of director competition (working in a rival company) as a director. Many scholars deviate from the ruling of the case as the case was the product of social, legal, and corporate development of its time, which is no longer relevant to the current situation of our world ${ }^{7}$. These scholars argued as the ruling of the case was based on the situation were the directors often appointed as non-executive directors to promote a company's profile, without having an active role in the company ${ }^{8}$. They asserted as this uncompromisingly rigid approach is not an appropriate legal response to the modern corporation which would, in some ways different and inconsistent with the dominant judicial thinking of the time ${ }^{9}$. Therefore in modern times directors are not allowed to compete against his/her company except allowed to do so by fulfillment of substantive and procedural conditions provided under the commercial law of each country ${ }^{10}$.

\section{Duties of Directors and Non-Competing Obligation}

As agents of a company, directors are under obligation to promote and protect the interests of the corporation whose affairs they are orchestrating. They have duties to discharge of a fiduciary nature towards their principal ${ }^{11}$. OECD corporate governance principles also recognized the monitoring and managing role of the board of directors to prevent potential conflicts of interest by management members and shareholders, by the way of misuse of corporate assets ${ }^{12}$. The principles also recognized and bestowed them with fiduciary duties to act on a fully informed basis, in good faith, with due diligence and care, and in the best interest of the company as well as shareholders ${ }^{13}$. This fiduciary duty is used to cover many aspects of the director's obligation to act in good faith for the benefit of the company as a whole ${ }^{14}$. There are some duties that emit from the fiduciary status of corporate directors. These are the duties of obedience, loyalty, and due care ${ }^{15}$. The duty of obedience requires a director to avoid committing any acts beyond the scope of the powers of a corporation as defined by its charter or the laws of

\footnotetext{
${ }_{1}^{1}$ Feldner, Denise: Redesigning Organizations, Concepts For The Connected Society, Springer Nature, 2019, P. 101.

2 See, Ecc, Art. 355. Also, Turkish Commercial Code, 2012, Article 396.

${ }^{3} \mathrm{Su}$, Wang: Non-Compete Obligation Of Directors In China's Company Law, Icassr, 2015, P. 384

${ }^{4}$ Editors, Law Review, P. 324.

${ }^{5}$ See, Nicholas Bourne: Essential Company Law, $3^{\text {rd }}$ Edition, Cavendish Publishing, 2000, P.66.

${ }^{6}$ Christie, P. 512. Read, Bourne, Nicholas: Principles Of Company Law, $3^{\text {rd }}$ Ed., 1998, P. 145.

${ }^{7}$ Le Miere, Dominique: London \& New Mashonaland Exploration Co Ltd V New Mashonaland Exploration Co Ltd: Is It Authority That Directors Can Compete With The Company? University Of Western Australia Law Review Vol 42:98, 2017, P. 103. Also Bourne, 2000, Pages 67. See Also, Ross Grantham, Can Directors Compete With The Company?, The Modern Law Review , Jan., 2003, Vol. 66, No. 1 2003, P. 110.

${ }^{8}$ Gower/ Davies: Principles Of Modern Company Law, Sweet \& Maxwell, Thomson Reuters, $9^{\text {th }}$ Ed. 2012, P. 518. See Also, Le Miere, 2017, P. 104

${ }^{9}$ Christie, P. 510

${ }^{10}$ The substantive and procedural legal condition provided in many countries Commercial Code includes pre-transaction general assembly approval of any competitive activities. See, TCC art. 396; ECC, art. 355

${ }^{11}$ Christie, p. 511.

${ }^{12}$,. OECD, Principles of Corporate Governance, OECD publishing 2004, p. 24.

(http://www.oecd.org/corporate/ca/corporategovernanceprinciples/31557724.pdf)

${ }^{13}$, OECD, p. 59. See also, IDOWU/CALIYURT, p. 300.

${ }^{14}$ Bourne, Nicholas: Principles Of Company Law, $3^{\text {rd }}$ Edition, 1998, P. 139.

${ }^{15}$ Clarke, Thomas: International Corporate Governance, a Comparative Approach, Routledge, 2007, P. 36.
} 
the state of incorporation ${ }^{1}$. This statutory obligation compels them to foster the company's business relationships with suppliers, customers, and others ${ }^{2}$. The duty of loyalty dictates that a director must act in good faith and must not allow his personal interest to prevail over the interests of the corporation ${ }^{3}$. This duty includes a duty to avoid conflicts of interest through entering into contracts with the company without the approval of the shareholders following full Disclosure, trading inside by using information and competing with the company ${ }^{4}$. The duty of due care requires a director to be diligent and prudent in managing the corporation's affairs ${ }^{5}$. It encompasses the duty to promote the success of the company, to act in good faith and in the best interests of the company. In general, fiduciaries unless otherwise expressly provided, are not allowed to put themselves in a position where their interests and duties conflict ${ }^{6}$.

Under both Ethiopia Commercial Code (hereinafter ECC) and Turkish Commercial Code (hereinafter TCC), directors owe fiduciary duties to the company. ${ }^{7}$ This fiduciary duty will be enforced by the company itself. But exceptionally shareholders can enforce the infringement of a fiduciary duty against a director through the company itself by means of derivative action on the company's behalf ${ }^{8}$. The fiduciary given under the Turkish Commercial Code include the duty of care and loyalty of the Board of Directors and third parties in charge of company management to be held liable for prudent performance and protection of the company's interests ${ }^{9}$. Similarly, under ECC, directors are jointly and severally liable to act with due care in relation to general management ${ }^{10}$. Article 364 of ECC also imposed Director's responsibility to show and demonstrate their due care and diligence while exercising the duties imposed on them by law, the memorandum or articles of association and resolutions of meetings as an agent of a company ${ }^{11}$. The mere shadow of disloyalty and a finding of fiduciary breaches are not dependent upon a lack of good faith or proof of loss ${ }^{12}$. The occurrence of an act that breaches the noncompetition obligation is sufficient for the enforcement of the sanctions under the Turkish legal system. There is no additional need for damages to be incurred by such an act ${ }^{13}$.

It can be readily observed that competing against companies or serving on the boards of two competing companies would raise obvious conflict of interest. The main conflict that could arise is the situation where two companies deal with each other that slide directors to prefer their own interests over the interests of the company ${ }^{14}$. This will erode the fiduciary duties of directors towards the company they favor. Generally, illegal use of information or opportunity which comes to the director because of his/her position in the company will very likely to be a breach of his fiduciary duty to the company even if he tries to disassociate himself from the company by saying he is acting in a private capacity on this occasion ${ }^{15}$. Hence there should be legal mechanisms at the place to put directors under legal bridles via some controlling mechanism such as non-competition obligation in case they act against established fiduciary relationship during his tenure of directorship. The law also brings into being other means of controlling the director not to compete against the company's interest after leaving the directorship position. These include non-solicitation ${ }^{16}$, non-dealing ${ }^{17}$, and non-poaching covenants or an express confidentiality provision to protect the privacy of commercially sensitive and strategic information ${ }^{18}$. Non-compete clauses and restrictive covenants in directors' service contracts are the traditional instruments by which companies try to ensure that their senior officers will not engage in competing business activities during employment and, sometimes, after their employment ends ${ }^{19}$. But to protect a company from key personnel setting up in competition, in addition to non-competition clauses often included in director's contracts, there has to be fair and protective legislation provided in company law ${ }^{20}$. Therefore it is obligatory for the company law to enact basic legal formula that considers the interests of the director on one side and the company's interests on the other side by way of unveiling

\footnotetext{
${ }^{1}$ See, Clarke, P. 36

2 See, Clarke, P. 36

${ }^{3}$ Clarke, P. 36. See Also, Bourne, 2000, P. 63

${ }^{4}$ Maynard, Paul: The Duty Of Loyalty From Directors, Partners And Senior Employees, Gaby Hardwicke Solicitors, 2014 , P, 3.

${ }^{5}$ Clarke, P. 36.

${ }^{6}$ Christie, P. 507

${ }^{7}$ See, ECC, art. 364; TCC, art. 553.

${ }^{8} \mathrm{TCC}$, art. 553; ECC, art. 367.

${ }^{9}$ See, TCC, art. 369 .

${ }^{10} \mathrm{See}$, art. $364 \mathrm{sub}$ art. 3

${ }^{11}$ See, ECC article 364 sub-art. 5.

${ }^{12}$ Grantham, P. 112.

${ }^{13}$ Altaş, Soner: Yönetim Kurulu Üyeleri Şirketle İșlem Yapma Ve Rekabet Etme Kararlarında Oy Kullanabilirler Mi?, Mali Çözüm, TemmuzAğustos, 2016, P. 147. Also See Temur, Fatih/ Göksu, Bekir: Application Of Noncompetition Obligation With Respect To The Partners And Company Directors, GSI Articletter, 2018, p. 137.

${ }^{14}$ Christie, P. 506. Bourne, 2000, P. 66.

${ }^{15}$ Dine, Janet: Company Law, Fourth Edition, 2001, p. 223.

${ }^{16}$ Webster, Martin: The Director's Handbook: Your Duties, Responsibilities And Liabilities, Kogan Page Publishers, 2007, P. 87.

${ }^{17}$ Webster, P. 87

${ }^{18}$ Webster, P. 88

19 Przewoznik, Anna: Non-Compete Obligations, Employment Update 2013, P. 8, (Https://Bateswells.Co.Uk/WpContent/Uploads/2019/06/Employment-Winter2013-Pdf.Pdf)

${ }^{20}$ Przewoznik, P. 8
} 
legal grounds within the scope of impartialities.

\section{Legal Scope of Director Non-Competition Obligation}

Director non-competition obligation is intended to prevent corporate insider who knows the secrets of the corporation from impairing corporation by utilizing their positions for unfair competition ${ }^{1}$. Non-competing obligation can be from the subjective and objective perspectives based on the individual person and transaction activities scope recognized by law respectively ${ }^{2}$. The prohibition of competition of commercial proxies, including executive directors appointed by the board of directors, non-executive directors, manager, organizer, founder, employee, consultant, agent, or representative, CEO or general manager, the secretary of corporation, Auditor, an officer of the court, liquidator, supervisory board members, shareholders (influential shareholder) and employees of the corporation can be seen in a line of the subjective perspective of director non-competition obligation ${ }^{3}$. Whereas the objective view of limitation is from perspectives of corporate activities (business area), geographical areas (location such as a country, region or a continent intended for company activities) and duration of prohibition from which directors are prohibited not to compete from working in the same industry or position in another state where it does not do business ${ }^{4}$.

The TCC and ECC imposed a duty of care and loyalty on the director ${ }^{5}$. Furthermore, both countries are concerned for corporate reputation and enacted a minimum standard which is aimed to protect companies from the unregulated competition with the director under article 396 and 355 respectively. Ethiopia Commercial Code under the sole legal provision of the code regarding share companies directors (Public Limited Companies) ineptly regulated as 'Unless authorized by a general meeting, directors may not be partners with joint and several liability in rival companies nor compete against the company either on their own behalf or on behalf of third parties ${ }^{6}$. Turkish Commercial Code also enacted vividly Director Non-competition obligation under article 396 as "no board member can conduct any transaction of a commercial nature falling under the scope of activity of the company in his/her account or any other person's account without obtaining permission from the GA, and he/she cannot participate in a company involved in the same kind of commercial business as a partner with unlimited liability ${ }^{7}$."

A literal reading of article 355 of Ethiopia Commercial Code Amharic version and English version of ECC has a little bit difference in terms of the message they convey for the reader. The Amharic version ' $\omega \cdot \varrho_{0} \rho_{0} C_{\text {' }}$ '

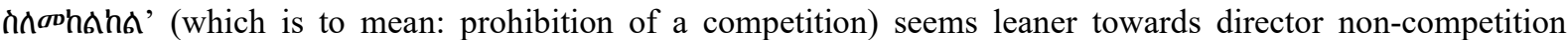
obligation than the English version of 'Restrictions on private trade' even though Amharic version has binding authority over English ${ }^{8}$. Also, the overall meaning of the Amharic version is better to give sounder meaning than the English version that even looks like contradictory. It prohibited directors from being a partner in a rival company with joint and several liabilities. In addition, it also disallowed these directors competition in person or representing any third parties (i.e. as a commercial agent, business commissioner, trade officer) against companies ${ }^{9}$.

Generally, both countries tried to confine the director's competition with the corporation but the language ECC used to clarify the scope of business activities directors are circumscribed to participate personally as well as on behalf of the third person are vague and intricate. The terminology used has a meaning difference in terms of limiting the scope of the transaction. The TCC used "...the scope of activity of the company......the same kind of commercial business...." to limit and clarify the extent of activities directors are banned to do. This allows directors to engage in any commercial activities that are not conducted by the company. But the ECC English version used ambiguous terminology which is general and open for misconception.

\section{a. Persons Subject to Non-Competition Obligation}

Plainly under ECC, it is only members of the Board of directors that were foisted with the obligation not to compete with the corporation. Other senior management members such as CEO or general manager, company secretary, as

\footnotetext{
${ }^{1}$ Dine, P. 221.

${ }^{2}$ Read To Understand More, Talbot, Lorraine: Critical Company Law, Routledge-Cavendish, 2008, P. 172. Read Also, Temur/Göksu, 2018, P. 135.

${ }^{3}$ Sinclair, Neil/ Geraghty, Sean/ Snowden, Richard Qc (Editors): Company Directors: Law \& Liability, Sweet \& Maxwell, $2^{\text {nd }}$ Ed. 2012 , P. 42. ${ }^{4}$ This works is dedicated to both subjective and objective non-competition obligation of management of corporation while directors are directing the corporation. Post-contractual non-competition obligation will be discussed under another work of the author.

${ }^{5}$ Whether this 'loyalty' in itself is enough to prevent director from competing against the company is debatable in academic arena. But one thing clear is the role of the court in entertaining such case is important to consider established corporate norms. It needs interpretation and situational understanding to extend fiduciary duties to include not to competition obligation.

${ }^{6}$ See Art. 3555 of ECC. Under this code, it is only this provision that prohibit expressly share companies directors from competition.

7 TCC, art. 396

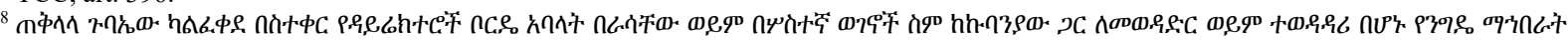

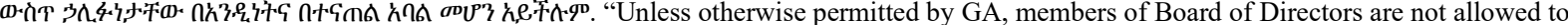
compete against the company or to participate as a member in rival companies with joint and several liabilities on their own behalf or on behalf of third parties." (The translation is done by author this article).

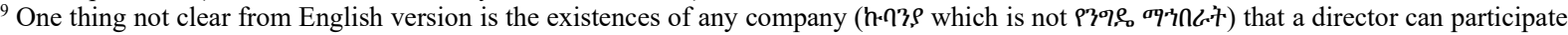
as partner with joint and several liabilities. But this article need clarification if it include corporate directors not to become a limited partner of article 296 of limited partnership of commercial code which is only severally liable to the extent of his/her contributions.
} 
well as auditors and influential shareholders are not embodied with such obligation ${ }^{1}$. So it is possible to argue that these bypassed members of the company are not subject to a prohibition of competition in the limited liability company under ECC since the law is not clear and imperative in a way that allows discourse.

Turkish Commercial code tried to inclusive in this case, to incorporate all management members of the corporation to be belted by non-competition obligation. Like ECC, Article 396 of TCC directly included directors of the company under the obligation. Those insiders of share companies corporate management other than the Board of Directors such as CEO, commercial agents, trade officers and other signatory that are not included under the scope of this article (396) will be subject to article 553 of the Turkish law of obligation ${ }^{2}$.

Under Ethiopia Commercial Code except for directors of share companies and managers of general partnership (art. 291), non-competition obligation regulation was not plainly provided regarding managers of a private limited company, joint venture, ordinary partnership and limited partnership of business organization ${ }^{3}$. Contrary to the ECC legislative experiences, article 626 sub 2 of TCC prohibited managers of limited liability (Private limited company) companies from the competition in an articulated manner.

"The managers cannot act in competition with the company except the articles of association provided to do so or with all other shareholders written consent. The articles of association may provide the approval decision of the general assembly instead of the approval of the shareholders."

A business organization other than Joint Stock Company and Private Limited Company non-competition obligation is regulated by Turkish Law of Obligation article 626 that barred the partners to engage in transactions for their own individual interest or third parties interest that would harm the purpose of the partnership ${ }^{4}$.

Turkish regulatory experience shows that ECC has a limitation in containing other senior management members such as general manager (CEO) who has more valuable information than Board of Directors under noncompetition obligation. Also, it demonstrated as there is a clear legal gap in apparently regulating non-competition obligation of the manager of private limited companies and other business organization managements except article 292 that restricts partners of the general partner to carry out transactions on behalf of a third party or on their own behalf without partner agreement ${ }^{5}$.

\section{b. Scope of Business Transaction Prohibited}

The non-competition obligation of directors of the company should not exceed the statutory corporate purpose and the commercial activity of the company. It has to be a reasonable agreement that should not keep the management of companies out of entire sector business activities in all areas. If the law is not clear enough to address the scope of a business transaction prohibited in a manner free from ambiguity, it will raise legal deficiency to prove director involvement in the alleged competing business that would fail to show directors actual operation of a business of the same kind and exploitation of his/her position to embezzle the corporate business opportunities.

In this case, the Turkish Commercial Code provision clearly confined the non-compete obligation only to the businesses that the company actually performs and which are carried out with a commercial purpose. Article 396 narrowed the scope to '... the scope of activity of the company ...... the same kind of commercial business....' not to include a business that is merely mentioned in company articles of association, but the business not actually performed by the company ${ }^{6}$. Therefore board members are permitted to engage in such activities regardless of whether the activities are indicated in the scope and purpose clause of the articles of association as long as the company does not physically carry out the business activities ${ }^{7}$. In a relative similarity, Ethiopia Commercial Code English version used the "rival companies.... compete against" while Amharic version used "....Pa, P.P.C + PqC

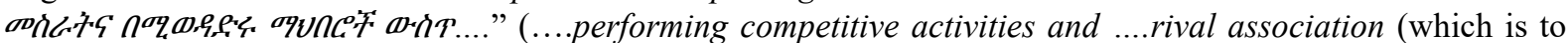
intended mean business association or companies....)) terminologies in trying to limit the scope of the noncompetition obligation of the director. The code utilized the jargon word "rivalry" that lacks illustration as it can be extended to include methodology (procedure), geography, nomenclature, end products, customer, etc. In what manner rivalry is measured was not clearly graspable from this provision. It is possible to broaden its horizon infinitely beyond de facto activities that the company is dealing with. In absence of other supplementary regulation and court decisions that describe the transaction similarity in terms of nature, repetition or continuity, value,

\footnotetext{
${ }^{1}$ For an influential shareholder to be obliged under non-competition obligation there should be some legal obligation that must be enacted to regulate the collateral fiduciary relationship of shareholders. Unlike partners of the ordinary partnership of article 243 of ECC, there are no shareholders loyalty, due care (commitment) obligations to their fellow shareholders of the company in addition to the absence of a legal provision that restricts their competition with their corporation.

${ }^{2}$ GÖKSOY, Yaşar Can: Ortaklıklar Hukukunda Rekabet Yasaklarının Kapsamı, DEÜHFD, C. IX, Özel Sayı, s. 645

3 ECC recognized 6 types of business organizations. These are joint ventures (art. 271), general partnership (art. 280), ordinary partnership (art. 227), limited partnership (art. 296), a private limited company (art. 510), and Share Company (art.304).

${ }^{4}$ GÖKSOY. P. 647

${ }^{5}$ When we compare article 292 and 355 of ECC together, the former article that prohibits partners of the general partner is more clear, precise, and easy to understand. It also addresses the business scope issue clearly to narrow interpretational difference within the same legal system.

${ }^{6}$ Altaş, P. 147. See Also, Öncel, Erman: Non-Compete Obligation Of Board Of Directors Members In Joint Stock Companies, 2015, P. 2. See Also, Kirca, İsmail / Manavgat, Çağlar / Şehirali Çelik, Feyzan: Anonim Şirketler Hukuku, Temel Kavram Ve İlkeler, Kuruluş, Yönetim Kurulu, Cilt 1, Ankara 2013, S. 692

7 Öncel, P. 2.
} 
methodology, and objective of the transaction, prohibiting in such a general way has detrimental consequences on directors. As it is, this provision is in favor of corporations with the concomitant effect of tying the directors in the board room by banning them not to do other life-changing businesses out of the corporate range of activities. It is recommended for a law to be peculiar in a manner of restricting director not to compete in a business which falls under the scope of activity of the company, which can be defined as de facto activities that companies engaged in. Narrowly interpreting the prohibition of competition will complement the constitutional rights of individuals to engage freely in economic activity and to pursue a livelihood of his choice anywhere within the national territory ${ }^{1}$. Also, it supplements the competition policy and regulation of the country compromisingly by restricting corporate monopoly within a regulated manner and preventing individual directors from misappropriating corporate strategic and functional activities.

\section{c. Exception for Director competition}

The general assembly of companies under both ECC and TCC are granted the authority to relieve the members of the board of directors of the company from the noncompetition obligation. After securing such authorization, such members are allowed to engage in activities that fall within the scope of the company's field of operation ${ }^{2}$. It is accepted that the general assembly, which is authorized to lift the ban, is also authorized to narrow it. The narrowing can be in the form of allowing the general assembly to take one of the transactional activities considered to be competitive such as allowing competition to take place personally without entering rivalry companies ${ }^{3}$.

The procedural mechanism of the relieving board of directors from such obligation is not pellucid under both Commercial Codes. Whether it is given based on individual director application or as Board of Directors in general, is not comprehensible. Except for TCC's 'no board member' and ECC's 'directors' vernacular terminologies, there is no legal provision to this concern about the relieving of noncompeting obligation granting procedure to the directors. But there are some views in the Turkish corporate governance literature to this concern. The first view is the individual based relieve of non-competition obligation. According to this viewpoint, the Board of Directors members require permission from the general assembly individually ${ }^{4}$. In such situation, the general assembly will take into consideration the personality of the person, moral characteristics, and professional equipment of the members to decide the competition fate of the director ${ }^{5}$. The relieve only concerns the current $\mathrm{BoD}$ members, not the future $\mathrm{BoD}$ members that will require permission procedurally as a newcomer. This is to mean that the decision of the approval of the General Assembly is for those who are still the members of the Board of Directors. In other words, if the duties of the members of the board of directors terminate for any reason such as resignation, death, expiration of the term of office, the new member cannot benefited from this permission ${ }^{6}$. The decision to allow the competition of one or a few board members based on their personal abilities cannot be interpreted as granting competition permits to all members of the board of directors ${ }^{7}$. The second opinion illustrated allowing of Board of Directors in the articles of association that will cover the Board of Directors members of all periods without individual personality consideration ${ }^{8}$. This will benefit anyone considered as a member of the board of directors. Generally, the permission given by the articles of association is abstract and general whereas permission by the general assembly is specific and personal ${ }^{9}$.

Another point to discuss here is, whether the permission given to members of the board of directors to compete with the company can be revoked. The available international experience shows the possibility of revocation that as the permission of competition is permitted individually, the decision to revoke should be evaluated according to the requirements of the work that the member who received the permit relied on and the revocation decision should be made according to each concrete case ${ }^{10}$.

The role of interested directors during the general assembly meeting (mainly vote casting) was not without hitch under Ethiopia commercial code unlike that of Turkish legal experiences that lucidly illustrated under article 436 by impeding any shareholders from participating in General Assembly meetings which are held to discuss a personal transaction or a legal/arbitral case between the company and himself/herself, his/her spouse, lineal kinship or the companies in which the same are shareholders ${ }^{11}$. Sub article 2 of the same article also prohibited shareholders who are also Board members or authorized signatories from participating in General Assembly meetings held to decide on releasing them from liabilities or obligations ${ }^{12}$. Illustratively in 2014 Turkish Supreme Court also

\footnotetext{
${ }^{1}$ Federal Democratic Republic Of Ethiopia Constitution, Proc. No. 1, 1995, Art. 41.

${ }^{2}$ See TCC, Art. 396; Ecc, Art. 355.

${ }^{3}$ Așik, Pınar: Anonim Şirketlerde Rekabet Yasağı (Ttk M. 396), Ankara Barosu Dergisi 4/7, 2017, P. 188.

${ }^{4}$ Aşik, P. 186.

${ }^{5}$ Aydoğan, Fatih: Ticaret Ortaklıklarında Rekabet Yasağı, İstanbul, 2005, P. 105.

${ }^{6}$ Assik, P. 187.

${ }^{7}$ Ayan, Özge: 6102 Sayılı Türk Ticaret Kanunu Çerçevesinde Anonim Şirket Yönetim Kurulu Üyelerinin Sadakat Yükümlülüğü Ve Bu Yükümlülüğün İhlalinin Sonuçları, Ankara, 2013, S. 156.

${ }^{8}$ Poroy, Reha/ Tekinalp, Ünal/ Çamoğlu, Ersin: Ortaklıklar Ve Kooperatif Hukuku, İstanbul 2014, P. 573.

${ }^{9}$ Poroy/ Tekinalp/ Çamoğlu, P. 573.

${ }^{10}$ Assik, P. 190

${ }^{11}$ TCC, art, 436 sub art. 1.

${ }^{12}$ TCC, art, 436 sub art. 2.
} 
extended the rule of prohibition not to participate in general assembly meetings to include families (spouse, husband), lineal kinship and Collateral kinship such as sisters, and brothers of board members who are also shareholders of the corporation ${ }^{1}$.

Likewise, Ethiopia Commercial Code under article 409 hampered members of shareholder companies from exercising their right to vote where the interests of a member, acting on their behalf or on behalf of a third party, conflict with the interests of the company. Additionally, the same article prohibited directors from participating in General Assembly meetings held to decide on the resolution relating to their duties and liabilities ${ }^{2}$. By the implementation of this article director who is also mandatorily shareholder under current commercial code, is not allowed to participate in the meeting that relieves them from liabilities or obligations not to compete with a company. But our legal practice dawdle behind Turkish experience who exhaustively tried to reduce interested directors, shareholders and their third-person hands from participating in general meeting assembly to relieve him/her from the obligation not to compete.

\section{Liabilities of Directors}

Prohibiting the director not to compete against the interest of the company while directing the corporation for similar business objectives on one hand and scoring the economic gain for the other partners on his behalf or on third-person accounts at the same time is morally and legally acceptable. But banning in itself is not enough to shape the behavior of the director once he began to partisan towards his own interest while earning benefits from the principal company. The law must clearly inscribe liabilities and remedies for the violation of such impartiality duties. Different countries illustrated different remedies that include an injunction, setting aside the transaction/rescission, account of profits, damages, and demand from the employee in breach of disgorgement of illegal income and seek recovery for its losses ${ }^{3}$. Turkish legal framework provided two types of remedies if the director disregards the non-competition obligation provided under article 396. These are special and general remedies.

\section{a. Special Remedies}

Under this category of remedies, Turkish Commercial Code article 396 accorded the number of actual and instantaneous legal therapy for the corporation. The provision state that if the director violated the non-compete obligation, the corporation is given to demand compensation from the breaching Board member ${ }^{4}$. The damage of the company will be calculated based on the loss that happened to the company ${ }^{5}$. This is requested by nonparticipating directors ${ }^{6}$. The other option victim Corporations are allowed to do is considering the concerned transactions as it was made in the name of itself and claim any benefits arising from that transaction ${ }^{7}$. The Board decides on which option will be preferred and the breaching board member cannot participate in the meetings held to make such a decision ${ }^{8}$. The third remedies sought if the transaction took place on behalf of a third-person account, the company can request the interests arising from the transactions made on the third party's account to be transferred to the company ${ }^{9}$. If the board member has engaged unlimitedly into another partnership dealing with the same business, requesting the board member to withdraw from the partnership or to transfer the interests gained in the partnership to the company is also one of the available remedies under article 396 of TCC $^{10}$. The board of directors can use only one of these rights in the provision and cannot claim these rights together ${ }^{11}$.

The law also enacted a period of limitation for such remedies to be requested within 3 months following the performance of the competing activity by the breaching board member or the date when the company becomes aware of such competing activity, and in any case, within 1 year following the performance of the competition $\operatorname{acts}^{12}$.

\section{b. General Remedies}

General liabilities are accessible remedy through a corporation in first hand and shareholders in the second hand as a derivative action that took place in the courtroom in case the shareholder's right infringement materialized. Under this fashion of remedies, the burden of proof belongs to the plaintiff who is shareholders or creditors and third parties in this case ${ }^{13}$. In addition to special remedies, Turkish Commercial Code under article 553 imposed

\footnotetext{
${ }^{1}$ Öncel, P. 2; See Also Altaş, P. 150.

${ }^{2} \mathrm{ECC}$, art. 409

${ }^{3}$ Bourne, 1998, p. 143.

${ }^{4}$ See TCC 396 sub-art. 1

${ }^{5}$ Aşik, p. 191.

${ }^{6}$ See, TCC 396 sub-art. 2.

${ }^{7}$ See, TCC 396 sub-art. 1

${ }^{8}$ TCC, art. 396 (2).

9396 sub art. 1.

${ }^{10}$ Aşik, P. 194.

${ }^{11}$ Așik, P. 195.

${ }^{12}$ Read, Art. 396 Sub Art. 4; Read Also, Temur/Göksu, P.138.

${ }^{13}$ Unlike the remedy of non-competition obligation under article 396, plaintiff must prove the negligence of the defendant and the existence of the damages in lawsuits arising out of Article 553. The burden of proof for article 553 is more detail and needs substantial occurrence of
} 
fault liability for the damages the company, shareholders, and creditors incurs up on founders, members of the board of directors, executives and liquidators in a circumstance they violate their obligations arising from the law and the articles of association ${ }^{1}$. Any shareholder can request compensation for damages; with a condition, payment will be made only to the company. The period of limitations for enforcing the general liability of non-competition obligation regulation infringement by directors under TCC is 2 years following the date the plaintiff becomes aware of the breaching activity and the damage incurred by the company. This period of limitation lapse in any way 5 years after the occurrence of the breaching activities ${ }^{2}$.

Ethiopia Commercial Code regulation also shows the enforcement of directors' liability belongs to the company as they owe a duty to the companies. They are jointly and severally liable to the company for damage caused by failure to carry out their duties ${ }^{3}$. But to put liability in motion in front of the court, the shareholders have to conduct the general meeting and decide a resolution for the legal proceeding to take place ${ }^{4}$. In case a resolution is adopted but the company fails to institute proceedings within three months, the shareholders who voted for the resolution may jointly institute proceedings ${ }^{5}$. Creditors are also entitled under our commercial code to institute Proceedings against the directors where the company's assets are insufficient to meet its liabilities ${ }^{6}$. Directors could fail to render its duty if he/she participates in one of the corporate arming activities including infringement of non-competing obligation. The code under article 367 allowed any shareholders or third parties who have been injured by the fault or fraud of the directors to institute a proceeding against the concerned director ${ }^{7}$.

It is clear from article 396 and 553 that special remedies given under article 396 of Turkish commercial law are far better easy to implement than the general remedies in terms of time, clarity, deterrence purpose, and procedural requirements. But in Ethiopia scenario, there is no special remedies given but even the general remedies inured under commercial code is full of procedural constraints that made it difficult for justice to be served as soon as possible for companies as well as for shareholders. Comparatively the investors were given broad remedies that construct their confidence in protecting hardly amassed capital under article 396 of Turkish commercial law in a far better way than ECC. This shows much more legal homework that the Ethiopia legislature has to do to have competitive corporate governance regulation that will attract more investors.

As we can understand from both article 396 of TCC and 355 of ECC, The non-competition obligation regulation was enacted to regulate while directors are on active duties of directorship position. This obligation of the director will come to an end with the expiration of the board membership of directors. Which is to mean that, a director will only owe fiduciary duties to his company for the duration of his directorship and that will come to an end upon his resignation or removed from the position. However, some of the duties that arise during the directorship have a continuing effect after the directorship has come to an end such as the duty not to exploit confidential information and maturing business opportunities ${ }^{8}$. This shows protecting corporations will continue reasonably even after the director left the position by a post-contractual non-compete obligation that play a far more significant role in upholding investor confidence in Limited Liability Company. Many countries enacted laws to avoid post-termination manipulation of business secret of the company by stipulating post-contractual noncompetition obligation with some compensation for a limited period ${ }^{9}$. In Ethiopia's case, article 355 seems clear regarding when the ban of competition of director will, as a rule, come to an end. But whether director noncompetition obligation prohibition can be extended by the decision of general assembly decision or articles of association or other contracts between director and company is not clearly provided. Even if it is not the concern of this article still fair and justifiable legal constrain that regulates the post-contractual non-competition obligation of the director is important for the benefit of the company.

\section{Conclusion}

As Directors are bestowed with the responsibility to do what is allowed in articles of association, general assembly resolution, and company law of the country, they are also allotted with the duty not to do some activities without authorization of GA that endangers the interests of the corporation. One of the responsibilities is not to compete against their company while also sitting in their position of directorship. The objective of such regulation is clearly

damages and existence of a fault

${ }^{1}$ TCC, art. 553

${ }^{2} \mathrm{TCC}$, art. 560

${ }^{3}$ ECC, 364 sub art. 2 .

${ }^{4}$ ECC, 365 sub art. $1,2$.

${ }^{5} \mathrm{ECC}, 365 \mathrm{sub}$ art. 4.

${ }^{6} \mathrm{ECC}, 366$.

${ }^{7}$ For this article to be executed in front of the court there should fault or fraud that needs substantial evidence from the plaintiff (in our case shareholders and third parties) to prove its materialization. This could be difficult for shareholders and third parties since those directors are more systematic than those plaintiffs when they plan and execute the action. They can easily conceal and rub out any evidence that makes them responsible.

${ }^{8}$ Maynard, p. 2.

${ }^{9}$ Under the Turkish legal system, there is agreement among scholars as article 444 of laws of obligation can be used for director post-contractual non-competition obligation. 
aimed to protect and prevent the members of the board of directors, who are familiar with the operation of the company, its working methods, management style, customer environment, business potential, and secrets, by using this information and thus damaging the company. With this objective, ECC provided directors not to compete obligation with the company without the consent of the General Assembly. Directors cannot engage (directly or as a partner with joint and several liabilities) in rival companies nor compete against the company either on their own behalf or on behalf of third parties. The code concentrated only on directors of the corporation while neglecting other senior management members of the company such as CEO or General Manager and corporate secretary who has a business secret, customer, and market situation as a director has. In this case, our code has a legal gap in considering other corporate families such as secretary, other officer or employee of a company in preventing them from improperly use of their position to gain an advantage that causes detrimental economic and slandering impact to the company, shareholders and the society.

Additionally, the scope of the business area that non-compete obligation apply was not elucidated. The code did not delineate the businesses that the company actually performs and which are carried out with a commercial purpose. The law should clarify and limit a business that is merely mentioned in the articles of association, but not actually performed by the company not to fall under the scope of the non-competition obligation. The directors have to be allowed to engage in such activities regardless of whether activities are indicated in the clause of the scope of the articles of association as long as the company does not physically carry out these activities. Such obligation of directors not to compete while they are on duty as well as post-termination (which is totally not addressed under ECC) must be carefully enacted to ensure that they are not a restraint of trade, makes director life difficulties on one side and also they must reasonably protect the corporate business interest on the other side. Turkish legal practice has resolved these issues under the article of 396 of TCC and Courtroom practices but ECC is lagging behind from the precision of regulating these important issues.

The other issues not addressed according to the reality and situation of limited liability companies under both the Current Commercial Code and Draft Commercial Law of Ethiopia is awarded legal remedy for companies in case director infringe non-competition obligation provision of commercial code. Our commercial code is restricted to general remedies that need procedural up and downs of general assembly resolution ( art. 365) and court proceedings that need efforts from companies shareholder to prove injury ensued by and fraud of the concerned director (367). Unlike the Turkish commercial code, Ethiopia's commercial code was impotent of considering special remedies that are efficient and more visible for the company's situation to implement without many procedural difficulties and without impacting concerned director basic rights.

Lastly, Ethiopia Commercial Code has also lacuna in regulating other business organization management members other than limited partners of the limited partnership. No legislation can be found to prevent private limited companies manager from competing with their companies. This also works for other remaining partnership business organization. In my humble opinion, it is the time for Ethiopia legislatures to reassess these far-reaching issues again for the benefit of all.

\section{References}

ALTAŞ, Soner (2016), Yönetim Kurulu Üyeleri Şirketle İşlem Yapma ve Rekabet Etme Kararlarında Oy Kullanabilirler mi?, Mali Çözüm Dergisi, Temmuz-Ağustos, Sayı 136, p. 145-151.

AŞıK, Pınar (2017), Anonim Şirketlerde Rekabet Yasağı (TTK m. 396), Ankara Barosu Dergisi 4/7, p. 165-202. AYAN, Özge (2013), 6102 Sayılı Türk Ticaret Kanunu Çerçevesinde Anonim Şirket Yönetim Kurulu Üyelerinin Sadakat Yükümlülüğü ve Bu Yükümlülüğün İhlalinin Sonuçları, Ankara, Turkey.

AYDOĞAN, Fatih (2005), Ticaret Ortaklıklarında Rekabet Yasağı, İstanbul, 2005.

BOURNE Nicholas (200), ESSENTIAL COMPANY LAW, 3rd edition, Cavendish Publishing.

BOURNE, Nicholas (1998), principles of company law, 3rd edition.

CHRISTIE, Michael (1992), The Director's Fiduciary Duty not to Compete, The Modern Law Review, Vol. 55, 4, p. 506-520.

CLARKE, Thomas (2007), International Corporate Governance, a comparative approach, Routledge.

DINE, Janet (2001), Company Law, Fourth Edition.

EDITORS, Law Review (1935) "Duty of a Director Not to Compete with His Corporation," University of Chicago Law Review: Vol. 2: Issue. 2, Article 36. p. 324-326. Available at: https://chicagounbound.uchicago.edu/uclrev/vol2/iss2/36,

FELDNER, Denise (2019), Redesigning Organizations, Concepts for the Connected Society, Springer Nature.

GÖKSOY, Yaşar Can (2005), Ortaklıklar Hukukunda Rekabet Yasaklarının Kapsamı, DEÜHFD, C. IX, Özel Sayı, p. 633-681.

GOWER/ DAVIES (2012), Principles of Modern Company Law, Sweet \& Maxwell, Thomson Reuters, 9th ed. 2012, p. 518-525.

GRANTHAM, Ross (2003) Can Directors Compete with the Company?, The Modern Law Review , Jan., 2003, Vol. 66, No. 1, p. 109-113. 
IDOWU, Samuel (ed)/ CALIYURT, Kiymet(ed) (2014), Corporate Governance, an International Perspective, book Series no.3, Springer Science \& Business Media.

KEAY, Andrew (2007), Company Directors’ Responsibilities to Creditors, Taylor \& Francis.

KIRCA, İsmail / MANAVGAT, Çağlar / ŞEHIRALI ÇELIK, Feyzan (2013), Anonim Şirketler Hukuku, Temel Kavram ve İlkeler, Kuruluş, Yönetim Kurulu, Cilt 1, Ankara Turkey.

LE MIERE, Dominique (2017), London \& New Mashonaland Exploration Co Ltd V New Mashonaland Exploration Co Ltd: Is It Authority That Directors Can Compete With The Company? University of Western Australia Law Review Vol 42:98, p. 99-127.

MARTIN, David (2007), The Company Director's desktop guide 6th edition.

MAYNARD, Paul (2014), the Duty of Loyalty from Directors, Partners and Senior Employees, Gaby Hardwicke Solicitors, p, 1-14.

ÖNCEL, Erman (2015), Non-Compete Obligation of Board of Directors Members In Joint Stock Companies, p. $1-3$.

PACCES, Alessio (2012) Rethinking Corporate Governance the law and economics of control powers, Routledge, London, UK.

POROY, Reha/ TEKINALP, Ünal/ ÇAMOĞLU, Ersin (2014) Ortaklıklar ve Kooperatif Hukuku, İstanbul, Turkey.

PRZEWOZNIK, Anna (2013), Non-compete obligations, Employment Update, p. 3-14. (https://bateswells.co.uk/wp-content/uploads/2019/06/employment-winter2013-pdf.pdf)

SINCLAIR, Neil/ GERAGHTY, Sean/ SNOWDEN, Richard QC (editors) (2012), Company Directors: Law \& Liability, Sweet \& Maxwell, $2^{\text {nd }}$ edition.

SU, Wang (2015), Research on Non-compete Obligation of Directors in China's Company Law, ICASSR, p. 384386.

TALBOT, Lorraine (2008), Critical Company Law, Routledge-Cavendish

TEMUR, Fatih/ GÖKSU, Bekir (2018), Application of Noncompetition Obligation With Respect to the Partners and Company Directors, GSI Articletter, p. 133-143.

WEBSTER, Martin (2007), the Director's Handbook: Your Duties, Responsibilities and Liabilities, Kogan Page Publishers. 